\title{
ANALISIS KESEHATAN BANK \\ BERDASARKAN KECUKUPAN MODAL, KUALITAS AKTIVA PRODUKTIF, MANAJEMEN, RENTABILITAS, DAN LIKUIDITAS (Studi pada BPR Siliwangi, Tasikmalaya)
}

\author{
Tedi Rustendi \\ Fakultas Ekonomi - Universitas Siliwangi
}

\begin{abstract}
Abstrak
Penelitian ini bertujuan untuk mengetahui pengaruh parsial dan simultan dari faktor CAMEL terhadap tingkat kesehatan bank. Data longitudinal selama lima tahun dikumpulan untuk dianalisis dan dideskripsikan dengan pendekatan studi kasus. Hipotesis diuji berdasarkan koefisien jalur dengan kaidah keputusan mengikuti uji dua arah dengan nilai kritis yang dibatasi oleh taraf nyata $5 \%$. Hasil pengujian hipotesis, secara parsial hanya faktor manajemen yang berpengaruh signifikan terhadap tingkat kesehatan bank, sedangkan secara simultan kecukupan modal, kualitas aktiva produktif, manajemen, rentabilitas, dan likuiditas berpengaruh signifikan terhadap tingkat kesehatan bank.
\end{abstract}

Kata kunci : CAMEL, dan Tingkat Kesehatan Bank.

\begin{abstract}
The partial and simultaneous influence of CAMEL factors on healt level of bank have been purpose of this research. Case study implemented for Descriptive analylis of longitudinal data in range five years. Instrument data analysis used path coefficient, and decision making accorded two tailed test with critical value that restricted $5 \%$ level of significant. The result of hipothesis testing were partially only management factor has significant influence on healt level of bank, and simultaneous all of CAMEL factors have significant influence on healt level of bank.
\end{abstract}

Keywords : CAMEL, and the healt level of bank

\section{Latar Belakang.}

Krisis perbankan di masa lalu telah memaksa Bank Indonesia untuk lebih memperketat penilaian kesehatan perbankan secara komprehensif. Aspek permodalan, kualitas aktiva produktif, rentabilitas, dan likuiditas dinilai secara terintegrasi dengan aspek manejemen umum dan risiko.

Hal tersebut dapat dipahami sebab sebagian besar permasalahan yang menimpa bank di Indonesia adalah aspek manajerial atas ke empat faktor di atas. Kasus Bank Century sebagai contoh mutakhir bank yang bermasalah/tidak sehat karena faktor permodalan dan buruknya kualitas aktiva produktif berimbas kepada menurunnya tingkat likuiditas sehingga gagal bayar. 
Pada kasus bank perkreditan rakyat yang dilikuidasi, fakta yang muncul kepermukaan adalah gagal bayar karena faktor kecukupan modal, tingginya kredit bermasalah yang mengoreksi tingkat rentabilitas dan menurunkan likuiditas yang diperparah oleh buruknya manajemen bank (biasanya terungkap setelah terbongkarnya kasus kejahatan perbankan). Aktivitas bank perkreditan rakyat yang terbatas dan terfokus kepada penghimpunan dana dan penyalurannya dalam bentuk kredit ikut mempengaruhi tingkat kerentanan bank bila terjadi masalah pada salah satu faktor tersebut di atas. Sebagai contoh, bila manajemen mampu menghimpun dana pihak ketiga, tetapi gagal dalam penyaluran kredit, maka bank menghadapi masalah dana menganggur, dan tingginya biaya dana. Biasanya manajemen akan mendorong aktivitas penyaluran kredit lebih besar (melakukan ekspansi kredit), sehingga risiko terjadinya kredit bermasalah pun meningkat. Kondisi tersebut dapat menjadi lebih buruk dengan faktor eksternal yang tidak terkendalikan yaitu persaingan dengan bank umum yang juga mengambil segmen pasar di sektor mikro, serta kondisi perekonomian yang penuh dengan ketidakpastian.

Bank Indonesia secara spesifik telah mengeluarkan peraturan mengenai batas minimal modal di setor untuk BPR, tata cara perhitungan dan pengakuan penyisihan kredit bermasalah yang lebih konservatif, standar pelaporan keuangan yang menekankan pengungkapan good governance, serta dilakukannya pengawasan yang lebih ketat berkenaan dengan tingkat likuiditas dari aspek keseimbangan penyaluran kredit dengan dana pihak ketiga yang dihimpun, dan batas maksimum pemberian kredit terutama kepada pihak terkait bank.

Langkah Bank Indonesia tersebut secara normatif dapat mendorong manajemen bank untuk mengelola operasional banknya secara hati-hati, serta lebih menekankan kepada aspek kesehatan bank sebagai perwujudan penerapan good governance.

\section{Identifikasi Masalah.}

Berdasarkan latar belakang tersebut, penulis mengajukan rumusan masalah sebagai berikut :

Bagaimana keterkaitan diantara faktor kecukupan modal, kualitas aktiva produktif, manajemen, earning dan likuiditas dalam upaya mencapai kategori bank yang sehat? 


\section{Kerangka Teoritis.}

Kinerja merupakan tolok ukur keberhasilan manajemen dalam mengunakan sumber daya secara optimal dalam satu periode tertentu (Malayu Hasibuan, 2006). Munawir (2004) mengemukakan bahwa hasil pengukuran kinerja digunakan untuk melakukan perbaikan operasional (bagi manajemen), pengambilan keputusan investasi (bagi investor), serta menjaga/meningkatkan kredibilitas perusahaan dimata investor, pelanggan ataupun masyarakat secara umum.

Salah satu tolok ukur keberhasilan manajemen dalam mengelola sumber daya secara optimal dapat dilakukan dengan pengukuran kinerja keuangan. Kinerja keuangan bagi lembaga keuangan bank menunjukkan bagaimana orientasi manajemen dalam menjalankan organisasinya mengakomodasi kepentingan manajemen (pengurus), pemegang saham (pemilik), pelanggan/nasabah, otoritas moneter, maupun masyarakat umum yang aktivitasnya berhubungan dengan perbankan. Oleh karena itu kinerja bank diukur dengan kriteria komposit dengan memberikan bobot tertentu kepada masing-masing indikator. Kinerja keuangan demikian sering disebut Tingkat Kesehatan Bank.

Agnes Sawir (2008) mengemukakan bahwa konsep kinerja keuangan bank menggambarkan kondisi keuangan pada satu periode tertentu baik yang menyangkut aspek penghimpunan dana maupun penyaluran dana. Penegasan yang menjadi landasan hukum tercantum dalam SK Direktur BI no 30/12/KEP/DIR berikut SE BI no 30/3/KEP/DIR th 1997 mengenai Penilaian Tingkat Kesehatan Bank Perkreditan Rakyat memuat kriteria komposit yaitu : (1) kecukupan modal ; (2) kualitas aktiva produktif ; (3) manajemen ; (4) rentabilitas/earning, dan ; (5) likuiditas. Disamping itu Bank Indonesia juga menegaskan keharusan bank untuk mematuhi ketentuan/peraturan yang berlaku.

Kecukupan modal diatur dalam SE Bank Indonesia no 8/28/DPBPR tahun 2006 sebagai faktor penting bagi bank yang harus dipenuhi dalam rangka pengembangan usaha dan menampung kemungkinan risiko kerugian. Bank Indonesia menetapkan bahwa indikator untuk mengukur kecukupan modal adalah CAR (capital adequacy ratio) yang dihitung berdasarkan aktiva tertimbang menurut risiko (perbandingan modal sendiri dengan ATMR). Selanjutnya Kasmir (2003) menegaskan bahwa CAR menunjukkan kemampuan bank dalam mengatasi kemungkinan kerugian akibat perkreditan dan perdagangan surat berharga. 
Kelangsungan usaha bank tergantung kepada kualitas penanaman dana dan kesiapan bank dalam menanggung kemungkinan timbulnya risiko kerugian dalam penanaman dana tersebut. Konsep yang berkenaan dengan hal tersebut dikenal dengan istilah kualitas aktiva produktif. Dalam konteks BPR, Bank Indonesia (1997) di atas membatasi aktiva produktif sebagai aktiva dalam rupiah maupun valuta asing yang dimiliki oleh bank dengan maksud untuk memperoleh penghasilan dari penanaman dana tersebut sesuai dengan fungsinya (kredit yang diberikan, surat berharga, dan penempatan dana pada bank lain kecuali giro). Secara konseptual, Hasanudin (2005) mengemukakan bahwa kualitas aktiva produktif merupakan penilaian aktiva produktif bank dengan beberapa penggolongan kesehatan bank berdasarkan aspek tertentu dan terukur yang ditetapkan oleh aturan perbankan. Penilaian aktiva produktif tersebut dijabarkan oleh Dahlan Siamat (2005) berdasarkan kepada ketepatan pembayaran kembali pokok dan bunga untuk kredit yang diberikan, dan tingkat kemungkinan diterimanya kembali dana yang ditanamkan untuk surat berharga dan penempatan pada bank lain. Bank Indonesia (1997) menetapkan indikator yang digunakan untuk mengukur kualitas aktiva produktif adalah Rasio KAP (perbandingan aktiva produktif yang diklasifikasikan dengan total aktiva produktif), dan Rasio PPAP (perbandingan PPAP yang dibentuk dengan PPAP yang wajib dibentuk).

Penanaman dana pada aktiva produktif pada pokoknya ditujukan untuk memperoleh laba. Kemampuan bank untuk memperoleh laba tersebut dikenal sebagai rentabilitas (Malayu Hasibuan, 2006). Lukman Dendawijaya (2005) mengemukakan bahwa rentabilitas tersebut juga merupakan alat untuk menganalisis atau mengukur tingkat efisiensi usaha. Bank Indonesia (1997) menetapkan bahwa indikator untuk mengukur rentabilitas bank adalah ROA (perbandingan laba bersih dengan rata-rata volume usaha), dan Rasio Efisiensi (BOPO) (perbandingan biaya operasional dengan pendapatan operasional). Indikator tersebut dapat menunjukkan kemampuan manajemen dalam menjalankan operasional bank dengan penggunaan sumber daya dalam penyaluran/ekspansi kredit serta menciptakan pendapatan bank secara keseluruhan.

Penyaluran/ekspansi kredit yang dilakukan bank harus memperhatikan kondisi keuangan bank guna menyangga likuiditas. Hal tersebut menjadi sangat penting mengingat sebagaian besar dana bank adalah milik pihak ketiga yang dapat ditarik kapan saja dalam jangka pendek. Bank Indonesia (1997) menetapkan reserve 
requirement atau cash ratio 5\%, dan LDR (loan to deposit ratio) maksimal $115 \%$. Dahlan Siamat (2005) memberikan batasan likuiditas sebagai kemampuan bank untuk memenuhi semua penarikan dana oleh deposan, kewajiban yang jatuh tempo, dan memenuhi permintaan kredit tanpa ada penundaan. Sejalan dengan konsep tersebut, Bank Indonesia (1997) menetapkan bahwa likuiditas diukur dengan indikator Cash Ratio (perbandingan alat likuid dengan kewajiban lancar), dan LDR (perbandingan kredit yang diberikan dengan dana yang diterima).

Faktor kecukupan modal, kualitas aktiva produktif, rentabilitas, dan likuiditas merupakan faktor keuangan yang bergantung kepada manajemen umum dan manajemen risiko yang dijalankan oleh pengurus bank. Bank Indonesia (1997) menegaskan 4 (empat) aspek manajemen umum yang meliputi strategi, struktur, sistem dan kepemimpinan. Sedangkan manajemen risiko terdiri atas 5 (lima) aspek yaitu risiko likuiditas, risiko kredit, risiko operasional, risiko hukum, dan risiko pemilik/pengurus. Aspek-aspek manajemen tersebut dijabarkan dalam Tata Cara Penilaian Tingkat Kesehatan Bank Perkreditan Rakyat (Bank Indonesia, 1997) sebagai indokator penilaian faktor manajemen.

Berdasarkan kriteria komposit, Kasmir (2003) berpandangan bahwa bank yang memiliki CAR yang tinggi berarti memiliki modal yang cukup kuat untuk menjalankan usahanya sehingga akan meningkatkan perolehan laba. Disisi lain perolehan laba yang dimaksud akan diperhitungkan sebagai modal inti (Bank Indonesia, 1997). Lebih lanjut Bank Indonesia menegaskan bahwa permodalan bank akan mempengaruhi dan dipengaruhi oleh kualitas penananam dana pada aktiva produktif. Oleh karena itu bank diwajibkan membentuk PPAP yang cukup dengan tujuan untuk menutup risiko kemungkinan kerugian karena penanaman modal dalam aktiva produktif. Faktor manajemen menjadi penentu bagaimana modal bank dikelola, sehingga terjadi keseimbangan diantara berbagai unsur/faktor penentu kesehatan bank, sementara di sisi lain, bank yang memiliki modal yang cukup akan memberikan keleluasaan bagi manajemen untuk menjalankan operasional bank secara sehat dalam batas-batas yang dapat ditampung oleh permodalan tersebut (Bank Indonesia, 2006). Dari aspek likuiditas, pemenuhan modal minimum 8\% dari ATMR (Bank Indonesia, 2006) memberikan kontribusi dalam menjaga likuiditas bank. Di sisi lain, likuiditas bank yang baik (dana yang cukup tertanam dalam alat likuid) akan berkontribusi dalam 
memelihara kecukupan modal mengingat alat likuid tersebut memiliki bobot risiko yang kecil dalam ATMR (Bank Indonesia, 2006).

Kualitas aktiva produktif berkorelasi dengan kemampuan bank dalam menghasilkan laba (rentabilitas). Konsep yang dikemukakan oleh Taswan (2005) dan Dahlan Siamat (2005) menegaskan hal tersebut yang menyebutkan bahwa aktiva produktif merupakan aset yang digunakan/dana yang disediakan untuk memperoleh pendapatan/penghasilan. Korelasional diantara kualitas aktiva produktif dengan rentabilitas tercermin dari tingkat kolektibilitas kredit yang menjadi dasar bagi penentuan beban PPAP. Dari aspek likuiditas, semakin baik tingkat kolektibilitas kredit yang diukur dengan rasio NPL akan mencerminkan ketersediaan alat likuid yang aman, sehingga bank dapat memenuhi kewajiban jangka pendeknya, seperti yang dikemukakan oleh Dahlan Siamat (2005) bahwa likuiditas berarti memiliki sumber dana yang cukup tersedia untuk memenuhi semua kewajiban jangka pendek. Disisi lain, seperti yang ditetapkan oleh Bank Indonesia (1997) bahwa kontribusi alat likuid terhadap kualitas aktiva produktif ditunjukan dengan rendahnya/kecilnya persentase penyisihan penghapusan aktiva produktif dari alat likuid.

Soemarso (2003) menegaskan bahwa rentabilitas adalah hasil dari berbagai keputusan dan kebijakan yang dijalankan perusahaan. Agnes Sawir (2008) mengemukakan bahwa rentabilitas juga bertujuan untuk mengukur tingkat efektivitas manajemen dalam menjalankan operasional perusahaannya. Dalam prakteknya, kemampuan bank dalam menghasilkan laba akan berkorelasi dengan kepentingan bank untuk menjaga likuiditas. Dalam hal ini indikator LDR yang ditetapkan oleh Bank Indonesia (1997) yang dibatasi dengan angka maksimum 115\% mencerminkan bahwa bank harus memperhatikan keseimbangan antara kinerja dalam menghasilkan laba dengan kepentingan untuk menjamin/memelihara likuiditas.

Kriteria komposit tersebut di atas menggambarkan bahwa faktor-faktor kecukupan modal, manajemen, aktiva produktif, rentabilitas, dan likuiditas dapat berkontribusi secara bersama-sama dalam mencapai tingkat kesehatan bank yang diharapkan baik oleh manajemen, pemilik maupun otoritas moneter. 
Kerangka pemikiran mengenai keterkaitan antar variabel dapat digambarkan sebagai berikut :

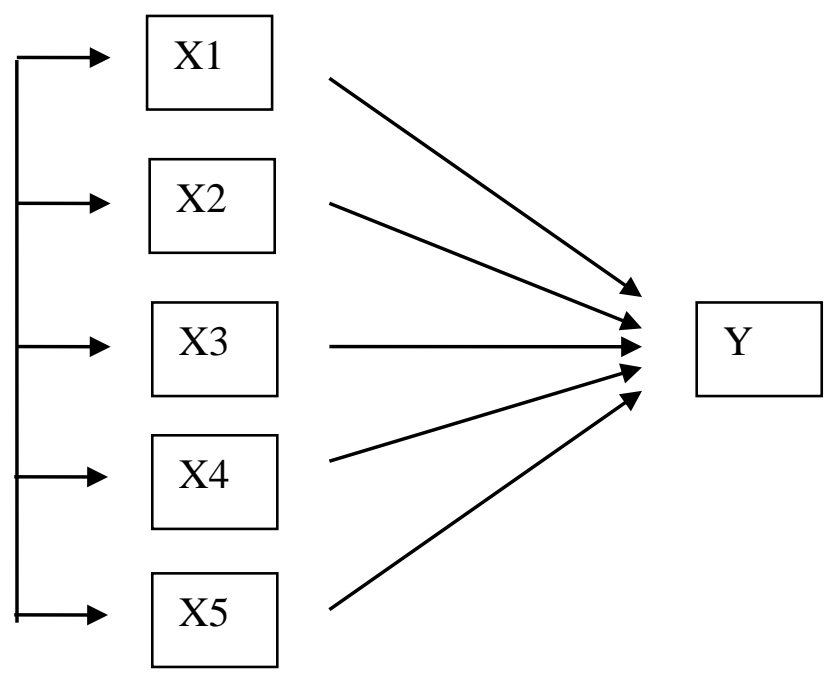

Gambar 3.1

Keterangan :

Struktur Hubungan Antar Variabel

X1 : Kecukupan Modal , X2 : Kualitas Aktiva Produktif, X3 : Manajemen, X4 Rentabilitas, $\mathrm{X}_{5}$ : Likuiditas, dan Y : Tingkat Kesehatan Bank.

\section{Hipotesis.}

Berdasarkan kerangka konseptual tersebut, hipotesis dapat dirumuskan sebagai berikut : Kecukupan modal, kualitas aktiva produktif, manajemen, rentabilitas, dan likuiditas secara bersama-sama dan parsial berpengaruh terhadap tingkat kesehatan bank.

\section{Metode Penelitian.}

Penelitian dilakukan dengan menggunakan metode deskriptif studi kasus pada PT Bank Perkreditas Rakyat Siliwangi Tasikmalaya dalam kurun waktu 5 (lima) tahun terakhir yang terbagi dalam periode evaluasi internal semesteran (sesuai ketentuan Bank Indonesia), sehingga data yang dikumpulkan meliputi 10 (sepuluh) semester.

Variabel-variabel yang diteliti adalah : (1) X1 : Kecukupan Modal dengan indikator Capital Adequacy Ratio ; (2) X2 : Kualitas Aktiva Produktif dengan indikator Rasio KAP ; (3) X3 : Manajemen dengan indikator Manajemen Umum, dan Manajemen Risiko dengan skor dibobot berdasarkan ketetapan Bank Indonesia ; (4) X4 Rentabilitas dengan indikator ROA ; (5) $\mathrm{X}_{5}$ : Likuiditas dengan indikator Cash Ratio, dan ; (6) Y : 
Tingkat Kesehatan Bank dengan indikator Nilai Kredit Tertimbang berdasarkan ketetapan Bank Indonesia. Varibel-variabel tersebut diukur dalam skala minimal interval.

Alat analisis yang digunakan adalah Path Analysis, dan pengujian hipotesis menggunakan uji F untuk simultan, dan uji t untuk parsial dengan kaidah keputusan mengikuti uji 2 (dua) arah.

\section{Hasil Penelitian Dan Pembahasan.}

\subsection{Korelasional Diantara Kecukupan Modal, Kualitas Aktiva Produktif, Manajemen, \\ Rentabilitas, dan Likuiditas.}

Faktor kecukupan modal BPR pada dua tahun pertama pendiriannya masih sangat tinggi, hal tersebut dapat dipahami mengingat sebagaian besar dana yang diperoleh belum tersalurkan secara optimal dalam bentuk pemberian kredit. Sejalan dengan perkembangan penyaluran dana bank, faktor permodalan terkoreksi menurun namun masih dalam kondisi sehat bila dibandingkan dengan ketentuan Bank Indonesia mengenai modal minimum 8\%. Rasio permodalan bank kembali mengalami kenaikan yang disebabkan oleh adanya tambahan modal disetor sebesar Rp 450.000.ooo,oo yang berasal dari pemegang saham pengendali. Tambahan modal tersebut ditujukan untuk investasi dalam aktiva tetap yang diestimasi dapat memberikan kenaikan nilai ekonomis aktiva bersih dalam jangka panjang.

Sejalan dengan investasi dana bank pada pemberian kredit, muncul risiko adanya kredit bermasalah. Manajemen bank pada periode awal pendirian terlihat masih kurang memperhatikan prinsip kehati-hatian. Penyaluran kredit yang belum optimal dan kurang selektif, serta penanganan tunggakan yang kurang intensif mengakibatkan kualitas aktiva produktif relatif buruk. Sejalan dengan peningkatan kemampuan manajemen dalam mengelola bisnis bank, kualitas aktiva produktif cenderung semakin baik. Peningkatan dalam pemberian kredit diimbangi dengan pengelolaan kolektibilitasnya. Analisis kredit yang teliti, manajemen kredit yang memadai dan kredit bermasalah yang ditangani secara komprehensif memberikan dampak positif kepada kualitas aktiva produktif. Namun demikian berkenaan dengan penanganan kredit bermasalah, manajemen sebaiknya menghindari kebijakan yang bersifat 
administratif sehingga pengungkapan aktiva produktif lebih kepada aspek material daripada nilai bukunya.

Aspek manajerial dipengaruhi oleh faktor atribut yang melekat kepada individu pengurusnya dan faktor eksternal (regulasi, kondisi perekonomian, persaingan, dll) yang akan mendorong/memaksa pengurus untuk menyusun strategi dan mengimplementasikannya dalam operasional bank. Interaksi diantara faktor-faktor tersebut memberikan dampak yang berbeda-beda terutama kepada aspek manajemen risiko. Kopetensi manajemen yang meningkat karena faktor pengalaman dan pembelajaran nyatanya tidak cukup untuk mengelola operasional bank dengan baik. Kualitas manajemen dapat dipandang menurun karena kurang antisipatif/responsif terhadap potensi masalah misalnya dalam bidang perkreditan yang mengakibatkan meningkatnya kredit bermasalah seperti yang terjadi pada tahun 2010 semester kedua (NPL sekitar 2,73\% dari sebelumnya 1,97\%).

Kemampuan dalam menghasilkan laba sangat ditentukan oleh kualitas penanaman modal pada aktiva produktif dengan memperhatikan kepentingan untuk memelihara likuiditas. Pada periode awal pendirian bank, rentabilitas ekonomi masih rendah yang disebabkan oleh rendahnya volume usaha (kredit yang diberikan) dan tingginya biaya tetap yang harus ditanggung manajemen sehingga tingkat efisiensi bank masih rendah. Sejalan dengan peningkatan kinerja penyaluran dana aspek rentabilitas mengalami koreksi positif. Namun demikian, bila mempelajari karakterisitik faktor likuiditas, dan kualitas aktiva produktif, serta RKA bank terkait pembukaan kantor cabang yang baru, rentabilitas bank kemungkinan/berpotensi akan mengalami penurunan karena adanya kredit bermasalah, dana menganggur, dan tingginya biaya tetap bank akibat penambahan kantor cabang. Oleh karena itu momentum pembukaan kantor cabang sebaiknya digunakan untuk meningkatkan kinerja penyaluran dana dalam bentuk pemberian kredit.

Likuiditas merupakan faktor yang vital mengingat karakterisitik bank yang melayani institusi pendidikan tinggi melalui pengelolaan dana mahasiswa, sehingga alat likuid dipertahankan pada jumlah yang relatif besar. Namun demikian hal tersebut berdampak terhadap beban operasional bank (biaya dana) yang secara nyata mengoreksi negatif perolehan laba. Bank tampaknya mengalami ketidakseimbangan kinerja penghimpunan dana dengan penyaluran dana, hal tersebut tampak dari aspek likuiditas berdasarkan tingkat penyerapan dana pihak ketiga kedalam kredit yang 
diberikan yang berada pada kisaran LDR 58,79\%. Hal tersebut menunjukkan bank dalam kondisi sangat likuid apalagi rasio kas memiliki rata-rata $24,44 \%$, tetapi tidak menguntungkan bank dalam upayanya memaksimalkan rentabilitas.

Berdasarkan nilai kredit dibobot yang menggunakan ketentuan Bank Indonesia, secara umum, bank dapat dikategorikan sebagai bank yang sehat untuk semua komponen/faktor yang diteliti. Namun demikian, manajemen dituntut untuk memperbaiki kinerja penyaluran dana karena faktanya berdasarkan rasio likuiditas, pemberian kredit masih suboptimal (BI merekomendasikan LDR sekitar 85\%). Selain itu bank dituntut untuk menangani secara intensif kredit bermasalah yang menyebabkan kualitas aktiva produktif mengalami penurunan seperti yang ditunjukkan data pada periode terakhir yang diteliti. Aspek lain yang menjadi kunci keberhasilan bank adalah faktor manajemen yang dituntut mampu mengelola operasional bank berbasis risiko. Manajemen perlu merancang strategi dan mengimplementasikannya dalam penanaman modal bank pada aktiva produktif, menyeimbangkan kinerja penghimpunan dana dan penyalurannya dalam bentuk kredit, sehingga tujuan bank untuk memaksimalkan laba dapat diimbangi dengan tingkat likuiditas dan solvabilitas yang memadai.

Selanjutnya guna menguji hipotesis, data mengenai variabel-variabel yang diteliti diukur berdasarkan ketentuan Bank Indonesia, dengan periode semesteran dalam rentang waktu tahun 2006 sampai 2010, yaitu :

Tabel 7.1. Hasil Pengukuran Variabel Penelitian

\begin{tabular}{|c|c|c|c|c|c|c|}
\hline $\begin{array}{c}\text { Periode } \\
\text { (Smt) }\end{array}$ & $\begin{array}{c}\text { Kecukupan } \\
\text { Modal }\end{array}$ & $\begin{array}{c}\text { Kualitas } \\
\text { Aktiva } \\
\text { Produktif }\end{array}$ & Manajemen & Rentabilitas & Likuiditas & $\begin{array}{c}\text { Tingkat } \\
\text { Kesehatan } \\
\text { Bank }\end{array}$ \\
\hline 1 & 71,26 & 4,60 & 50 & 1,40 & 29,10 & 84,50 \\
\hline 2 & 48,15 & 3,80 & 55 & 2,40 & 35,10 & 85,00 \\
\hline 3 & 43,60 & 5,40 & 50 & 2,90 & 31,20 & 85,20 \\
\hline 4 & 38,90 & 4,13 & 62 & 4,36 & 31,69 & 86,40 \\
\hline 5 & 30,10 & 2,30 & 56 & 2,90 & 27,00 & 85,80 \\
\hline 6 & 25,53 & 2,10 & 58 & 3,50 & 20,80 & 86,00 \\
\hline 7 & 23,95 & 1,42 & 65 & 3,20 & 20,40 & 86,80 \\
\hline 8 & 22,31 & 1,24 & 70 & 4,40 & 16,60 & 87,40 \\
\hline 9 & 19,79 & 0,97 & 67 & 3,10 & 15,40 & 87,00 \\
\hline 10 & 22,14 & 1,90 & 66 & 4,50 & 17,10 & 86,70 \\
\hline
\end{tabular}

Sumber : BPR Siliwangi, diolah 
Tabel 7.2.

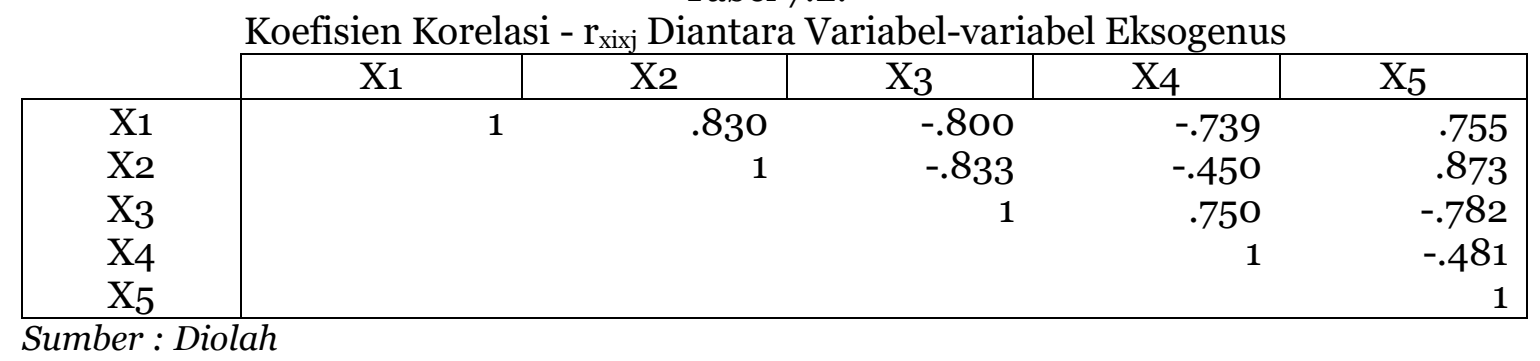

Berdasarkan uji statistik pada tabel 7.2. di atas, dapat diinterpretasikan bahwa terdapat korelasional ( $\mathrm{r}_{\mathrm{xixj}}$ tidak mendekati limit nol) diantara faktor-faktor kecukupan modal, kualitas aktiva produktif, manajemen, rentabilitas dan likuiditas. Namun demikian terdapat anomali korelasional antara kualitas aktiva produktif dengan likuiditas. Hasil penelitian menunjukkan, anomali tersebut disebabkan dana bank yang cukup besar dalam bentuk alat likuid yang menjamin likuiditas bank, sementara bank juga menghadapi kredit bermasalah yang cukup besar. Data tersebut menggambarkan bahwa faktor pemberikan kredit merupakan inti dari anomali tersebut, dimana kecilnya jumlah kredit yang diberikan (penghimpunan dana terus dilakukan) mengakibatkan adanya dana yang menganggur dalam bentuk alat likuid (likuiditas baik), tetapi kecilnya kredit yang diberikan akan menekan kualitas aktiva produktif karena tingginya kredit bermasalah.

Berdasarkan uji hipotesis pada critical value 1/2 $\alpha(\mathrm{n}-2)$ mengenai korelasional diantara variabel-veriabel eksogenusnya, maka Variabel Manajemen $\left(\mathrm{X}_{3}\right)$ dan Kecukupan Modal (X1) merupakan faktor dominan yang signifikan berkorelasi dengan variabel-variabel yang lainnya. Hal tersebut dapat dipahami mengingat inti dari operasional bank adalah bagaimana manajemen umum dan manajemen risiko diterapkan dalam mengelola permodalan bank guna mencapai tujuan yang telah ditetapkan dengan menjaga agar kualitas aktiva produktifnya baik sehingga bank mampu mengoptimalkan perolehan laba dan menjamin likuiditas bank pada posisi yang aman.

\subsection{Pengaruh Kecukupan Modal, Kualitas Aktiva Produktif, Manajemen, Rentabilitas, dan Likuiditas Terhadap Tingkat Kesehatan Bank.}

Uji hipotesis pada taraf nyata $5 \%$ baik secara parsial maupun simultan terhadap hipotesis penelitian disajikan pada ringkasan output spss v 17.0 di bawah ini : 
Tabel 7.3

Koefisien Jalur Variabel Eksogenus Terhadap Variabel Endogenus

\begin{tabular}{|l|r|r|r|r|r|r|}
\hline \multicolumn{1}{|c|}{ Variabel Eksogenus } & \multicolumn{1}{c|}{$\mathrm{p}_{\mathrm{yxi}}$} & $\mathrm{t}_{\text {statistic }}$ & Sig & $\begin{array}{c}\mathrm{P}_{\mathrm{yxi}} \approx \\
\mathrm{R}^{2} \mathrm{yxi}\end{array}$ & $\mathrm{F}_{\text {statistic }}$ & Sig \\
\hline Kecukupan Modal & -.408 & -1.764 & .152 & & & \\
Kualitas Aktiva Produktif & .299 & 1.009 & .370 & & & \\
Manajemen & .808 & 3.313 & .030 & .976 & 31.957 & .003 \\
Rentabilitas & -.035 & -.168 & .874 & & & \\
Likuiditas & -.136 & -.825 & .455 & & & \\
\hline
\end{tabular}

Catatan : Variabel Endogenus (Y) : Tingkat Kesehatan Bank

Sumber : Diolah

Berdasarkan tabel 7.3. di atas, hipotesis alternatif (Ha : $\mathrm{p}_{\text {yxi }} \neq 0$ ) yang menyatakan bahwa kecukupan modal, kualitas aktiva produktif, manajemen, rentabilitas, dan likuiditas berpengaruh secara parsial terhadap tingkat kesehatan bank, tidak sepenuhnya teruji pada taraf nyata $5 \%$, dimana hanya variabel Manajemen $\left(\mathrm{X}_{3}\right)$ yang berpengaruh signifikan terhadap Tingkat Kesehatan Bank, sementara variabel Kecukupan Modal, Kualitas Aktiva Produktif, Rentabilitas, dan Likuiditas tidak berpengaruh signifikan terhadap Tingkat Kesehatan Bank. Hasil pengujian hipotesis tersebut menempatkan variabel Manajemen sebagai faktor dominan yang secara langsung ataupun tidak langsung dalam menentukan hasil akhir Tingkat Kesehatan Bank. Hal tersebut dapat dipahami karena faktor kecukupan modal yang memadai, kualitas aktiva produktif yang baik, rentabilitas yang tinggi dan likuiditas bank yang terjaga/terjamin merupakan pencerminan dari kualitas manajemennya, sehingga bank tersebut dikategorikan sehat.

Sementara itu hipotesis alternatif ( $\mathrm{Ha}: \mathrm{P}_{\mathrm{yxi}} \neq 0$ ) yang menyatakan bahwa kecukupan modal, kualitas aktiva produktif, manajemen, rentabilitas, dan likuiditas berpengaruh secara simultan terhadap tingkat kesehatan bank teruji pada taraf nyata 5\%. Dengan demikian dapat dipahami bahwa tingkat kesehatan bank hanya dapat dicapai bila kelima unsur tersebut di atas berada dalam kondisi yang baik yaitu kondisi dimana terdapat keseimbangan antara kinerja penghimpunan dana dan penyaluran dana yang disertai dengan upaya peningkatan/pengembangan kompetensi sumber daya manusia, sehingga bank memiliki manajemen yang kompeten, didukung dengan modal yang cukup, aktiva produktif yang berkualitas, rentabel dan likuid.

Namun demikian, berdasarkan nilai koefisien jalur tersebut, diketahui bahwa terdapat nilai residu yang menunjukkan adanya faktor lain yang mungkin dapat 
mempengaruhi tingkat kesehatan bank, misalnya pelanggaran terhadap BMPK (Batas Maksimum Pemberian Kredit) baik kepada pihak terkait maupun tidak terkait bank.

\section{Penutup}

Berdasarkan pembahasan di atas, dapat disimpulkan bahwa faktor CAMEL, yaitu kecukupan modal yang memadai, kualitas aktiva produktif yang baik, manajemen yang kompeten, rentabilitas yang tinggi, dan likuiditas yang terjamin merupakan faktor yang harus dicapai secara serempak untuk menciptakan praktek bank yang sehat. Manajemen merupakan faktor dominan yang menentukan hasil akhir tingkat kesehatan bank baik secara langsung maupun tidak langsung melalui pengelolaan modal, penanaman dana dalam bentuk kredit, efisiensi penggunaan sumber daya ekonomi untuk menghasilkan laba, dan menjamin alat likuid yang memadai. Dalam prakteknya, faktor lain yang juga dipertimbangkan dalam upaya mencapai praktek bank yang sehat adalah keharusan untuk mentaati regulasi mengenai batas maksimum pemberian kredit.

Hasil penelitian ini dapat dipertimbangkan untuk perbaikan operasional bank dengan lebih fokus kepada upaya peningkatan/pengembangan sumber daya manusia agar memiliki kompetensi yang tinggi, sehingga mereka mampu mengelola sumber daya ekonomi yang dimiliki bank secara efektif dan efisien dengan tetap menjaga kepercayaan masyarakat dan mematuhi regulasi yang berlaku.

\section{Referensi.}

Agnes Sawir. 2008. Analisis Kinerja Keuangan Dan Perencanaan Keuangan Perusahaan. Jakarta. Penerbit : Gramedia Pustka Utama.

Bank Indonesia. 1997. SK Dir BI No 30/12/KEP/DIR berikut SE BI No 30/3/KEP/DIR Tahun 1997 tentang Tata Cara Penilaian Tingkat Kesehatan Bank Rakyat Indoensia.

. 2006. SE BI No 8/28/DPBPR Tahun 2006 tentang Kewajiban Penyediaan Modal Minimum.

Brigham, Eugene F., and Joel F. Houston. 2009. Fundamentals of Financial Management, $12^{\text {th }}$ edt. South-Western, Cengage Learning. Ohio.

Cheng-Few Lee (editor). 2008. Advance in Quantitative Analysis of Finance and Accounting, Vol 6. World Scientific Publishing Co. Pte. Ltd., Singapore.

Dahlan Siamat. 2005. Manajemen Lembaga Keuangan. Jakarta. Penerbit : Lembaga Penerbit Fakultas Ekonomi Universitas Indonesia. 
Hasanudin Rahman Daeng Naja. 2005. Hukum Kredit Dan Bank Garansi. Samarinda. Penerbit : Citra Aditya Bakti.

Kasmir. 2003. Manajemen Perbankan. Jakarta. Penerbit : Raja Grafindo Perkasa

Lukman Dendawijaya. 2005. Manajemen Perbankan. Bogor. Penerbit : Ghalia Indonesia.

Malayu S. P. Hasibuan. 2006. Dasar Dasar Perbankan. Jakarta. Penerbit : PT Bumi Aksara.

Munawir Slamet. 2004. Analisa Laporan Keuangan. Yogyakarta. Penerbit : Liberty

Soemarso S. R..2003. Akuntansi ; Suatu Pengantar. Jakarta. Penerbit : Salemba Empat.

Taswan. 2005. Akuntansi Perbankan. Yogyakarta. Penerbit : YKPN 